\title{
ANALISIS dan PENGEMBANGAN SISTEM INFORMASI AKADEMIK (SISFO) di UNIPDU JOMBANG
}

\author{
Mukhamad Masrur \\ Jurusan Sistem Informasi Fakultas Teknik \\ Universitas Pesantren Tinggi Darul Ulum Jombang
}

\begin{abstract}
Abstraksi
Inti dari analisis sistem ini adalah berusaha untuk melihat keseluruhan masalah dalam hubungannya, dengan cara sistematis menyelidiki tujuan sistem dan kriteria untuk berhasilnya sistem tersebut dan untuk menilai alternatif-alternatif dipandang dari sudut keberhasilan dalam mutu dan manfaat. Tugas penting dalam melakukan analisis sistem adalah memaksimumkan keberhasilan pemecahan dengan prosedur aplikasi sistem informasi yang tepat.
\end{abstract}

Keywords: Analisis, Sistem, Informasi, Akademik

\section{PENDAHULUAN}

Pentingnya suatu sistem informasi akademik yang terorganisir dengan baik akan sangat dirasakan oleh seluruh staf tata usaha bagian akademik di Unipdu Jombang, disebabkan selama ini setiap proses menjalankan aplikasi sistem informasi akademik (sisfo) belum bisa menghasilkan kinerja yang tepat pada proses data dan output yang diinginkan sesuai standart akademik yang telah ditentukan di unipdu, banyak faktor yang perlu diperbaiki sehubungan dengan kurang maksimalnya sistem yang diterapkan, diantaranya adalah aplikasi sisfo yang masih belum sesuai dengan standart kurikulum dan sistem yang dibutuhkan disetiap fakultas pada Unipdu Jombang.

Disisi perangkat keras penerapan teknologi masih banyak yang kurang memenuhi kebutuhan untuk aplikasi sisfo akademik sehingga sering terjadi crash pada aplikasi sisfo dan berakibat tidak digunakan pada waktu yang dibutuhkan. Terlebih para user input data pada aplikasi sisfo yang belum menguasai karakteristik aplikasi tersebut menimbulkan kendala lain, sehingga kinerja sistem informasi akademik tidak optimal.

Dari berbagai kendala yang ada menimbulkan kurang efektifnya manfaat aplikasi sisfo akademik di Unipdu Jombang, terutama pada saat hasil keluaran yang dibutuhkan harusnya sesuai waktu yang ditentukan sehingga mendapatkan sistem informasi yang akurat bagi semua pihak yang membutuhkannya.

Dibutuhkan devisi khusus untuk menangani aplikasi sisfo akademik, agar mampu mengembangkan kebutuhan sistem pada setiap Fakultas di Unipdu Jombang. Tentu dalam hal ini adalah Devisi Pengembangan Teknologi Sistem Informasi yang terdidik sesuai dengan program yang diterapkan di Unipdu Jombang. dan mampu bekerja sama dengan baik pada setiap Fakultas untuk mengembangkan SISFO Akademik di Unipdu Jombang

\section{LANDASAN TEORI}




\subsection{Pengertian Analisis}

Penguraian dari suatu sistem informasi yang utuh ke dalam bagian-bagian komponennya dengan maksud untuk mengidentifikasikan dan mengevaluasi permasalahan, kesempatan, hambatan yang terjadi dan kebutuhan yang diharapkan sehingga dapat diusulkan perbaikan.

Tugas utama dari menganalisis sistem meliputi :

- Menentukan lingkup sistem

- Mengumpulkan fakta

- Menganalisis fakta

- Mengkomunikasikan temuan-temuan tersebut melalui laporan analisis sistem

\subsection{Analisis Sistem}

Analisis PIECES

Sebagai alat ukur dalam menentukan sistem baru layak atau tidak, karena 6 aspek ini harus mengalami peningkatan ukuran yang lebih baik dari sistem lama.

\section{Analisis Kinerja (Perfomance)}

Peningkatan terhadap kinerja (hasil kerja) sistem yang baru sehingga menjadi lebih efektif. Kinerja dapat diukur dari throughput dan respon time. Throughput adalah jumlah dari pekerjaan yang dapat dilakukan suatu saat tertentu. Response Time adalah rata-rata waktu yang tertunda diantara dua transaksi atau pekerjaan ditambah dengan waktu respon untuk menanggapi pekerjaan tersebut.

\section{Analisis Informasi (Information)}

Peningkatan terhadap kualitas informasi yang disajikan. Apabila informasi yang disajikan lebih baik dari sebelumnya sesuai dengan waktu yang dibutuhkan dan sesuai dengan hasil yang diinginkan maka kualitas informasi tersebut mengalami peningkatan jika dibandingkan dengan sistem sebelumnya.

\section{Analisis Ekonomi (Economy)}

Peningkatan terhadap manfaat-manfaat atau keungtungan-keuntungan atau penurunan-penurunan biaya yang terjadi.

Total biaya saat menggunakan teknologi ini apakah lebih sedikit ataukah justru lebih meningkat. Maka itu disebut dengan nilai economy. Saat penerapan teknologi informasi sesungguhnya biaya besar di awal namun sangat minim biaya pada proses ke depan hingga membutuhkan pengembangan sistem selanjutnya.

\section{Analisis Kendali (Control)}

Peningkatan terhadap pengendalian untuk mendeteksi dan memperbaiki kesalahan-kesalahan serta kecurangan-kecurangan yang dan akan terjadi. Pentingnya sebuah kontrol dalam sistem agar tetap stabil atau lebih ditingkatkan fungsi dari kinerja sistem tersebut adalah pada pengendalian.

\section{Analisis Efisiensi (Efficiency)}

Peningkatan terhadap efisiensi operasi. Efisien berbeda dengan ekonomis. Bila ekonomis berhubungan dengan jumlah sumberdaya yang digunaka, efisiensi berhubungan dengan bagaimana sumberdaya tersebut digunakan dengan pemborosan yang paling minimum. Efisiensi dapat diukur dari output dibagi dengan inputnya.

\section{Analisis Pelayanan (Service)}

Peningkatan terhadap pelayanan yang diberikan oleh sistem. Dengan adanya sistem baru mampu memberikan pelayanan yang lebih dinamis sehingga mendapatkan proses lebih cepat, tanpa antrian panjang. 


\subsection{Siklus Hidup Pengembangan Sistem}

Pengembangan sistem informasi yang berbasis computer dapat merupakan tugas kompleks yang membutuhkan banyak sumber daya dan dapat memakan waktu berbulan bulan bahkan bertahun-tahun untuk menyelesaikanya. Proses pengembangan sistem melewati beberapa tahapan dari mulai sistem itu direncanakan sampai dengan sistem tersebut diterapkan, dioperasikan dan dipelihara.

Bila operasi sistem yang sudah dikembangkan masih timbul kembali permasalahan-permasalahan yang kritis serta tidak dapat diatasi dalam tahap pemeliharaan sistem, maka perlu dikembangkan kembali suatu sistem untuk mengatasinya dan proses ini kembali ke tahap yang pertama, yaitu tahap perencanaan sistem. Siklus ini disebut dengan siklus hidup suatu sistem (Systems Life Cycle).

Daur atau siklus hidup dari pengembangan sistem merupakan suatu bentuk yang digunakan untuk menggambarkan tahapan utama dan langkah-langkah didalam tahapan tersebut dalam proses pengembanganya.dan masuk akal. Di systems life cycle, tiap-tiap bagian dari pengembangan sistem dibagi menjadi beberapa

Ide dari systems life cycle adalah sederhana tahapan kerja. Tiap tiap tahapan ini mempunyai karakteristik tersendiri. Tahapan utama siklus hidup sistem dapat terdiri dari tahapan perencanaan sistem (systems planing), analis sistem (systems anayisis), desain sistem ( System Design), seleksi sistem (Systems Selection), Implementasi sistem (Systems Implementasion), dan perawatan sistem (systems maintenace)

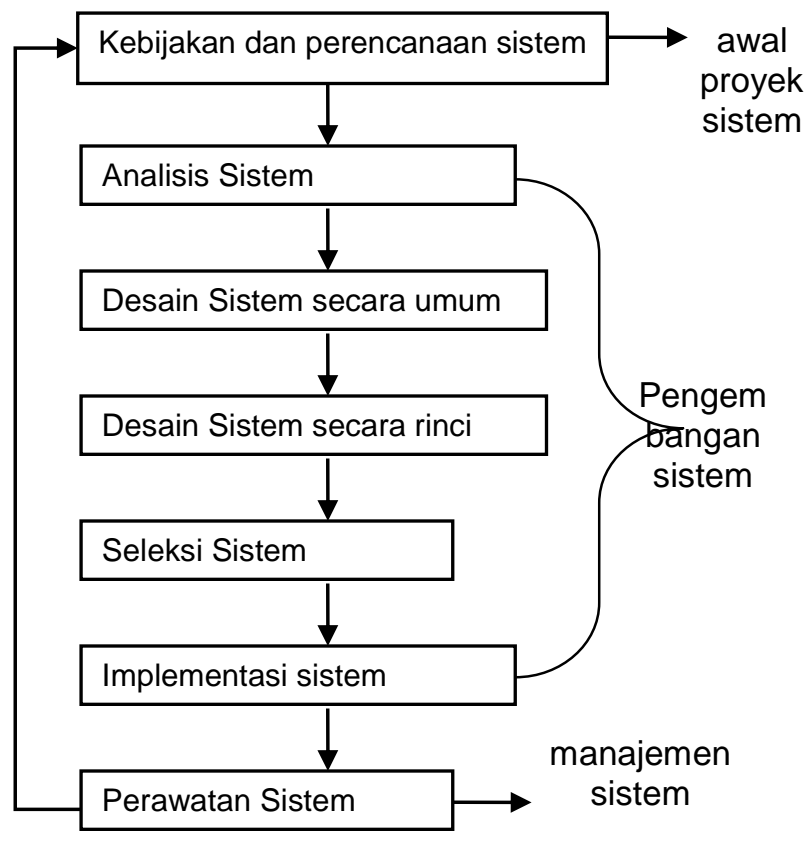

Gambar 1. Siklus Hidup Sistem

Analisis sistem dapat didefinisikan sebagai penguraian dari suatu sistem informasi yang utuh ke dalam bagian-bagian komponennya dengan maksud untuk mengidentifikasikan dan mengevaluasi permasalahan-permasalahan, kesempatan-kesempatan, hambatan-hambatan yang terjadi dan kebutuhankebutuhan yang diharapkan sehingga dapat diusulkan perbaikan-perbaikannya.

\section{Langkah-langkah analisis sistem :}

1. Identify (identifikasi masalah)

2. Understand (memahami kerja dari sistem yang ada) 
3. Analyze (menganalisa sistem)

4. Report (membuat laporan hasil analisis)

\subsection{Pendekatan Pengembangan Sistem}

○ Klasik vs Terstruktur

○ Sepotong vs Sistem

- Bottom up vs Top down

- Sistem Menyeluruh vs Moduler

- Lompatan Jauh vs Berkembang

\subsection{Alat Dan Teknik Pengembangan Sistem}

Untuk dapat melangkah sesuai dengan yang diberikan oleh metodologi pengembangan sistem yang tersetruktur maka dibutuhkan alat dan teknik untuk melaksanakannya. Alat-alat yang digunakan pada umumnya berupa suatu gambar atau diagram atau grafik. Penggunaan diagram atau gambar ini dipandang lebih mengena dan lebih mudah dimengerti.

Berbentuk Grafik :

- HIPO (Hierarchy plus Input Process Output)

- Data Flow Diagram

- Structured Chart

- Structured Analysis and Design Technique (SADT)

- Warnier/Orr diagram.

- Jakson's diagram

\subsection{Pengetahuan Dan Keahlian Analisis Sistem}

Analisis sistem harus mempunyai pengetahuan yang luas dan keahlian yang khusus. Beberapa analisis sistem setuju bahwa pengetahuan dan keahlian-keahlian berikut ini sangat diperlukan bagi seorang analisis sistem yang baik.

1. Pengetahuan dan keahlian teknik pengolahan data, teknologi komputer, dan pemrograman komputer.

2. Pengetahuan tentang bisnis secara umum.

3. Pengetahuan tentangmetode kuantitatif

4. Keahlian pemecahan masalah.

5. Keahlian komunikasi antar personil.

6. Keahlian membina hubungan antar personil.

\subsection{Team Pengembang Sistem}

Dalam proyek pengembangan sistem yang kecil dan sederhana, kemungkinan hanya ada seorang analis sistem yang merangkap sebagai pemrogram (analis/pemrogram) atau seorang pemrogram yang merangkap sebagai analis sistem (pemrogram/analis). Akan tetapi untuk proyek pengembangan sistem informasi yang besar atau komplek, pekerjaan ini biasanya dilakukan oleh sejumlah dalam bentuk team. Anggota dari team pengembangan ini tergantung dari besar kecilnya ruang lingkup proyek yang akan ditangani. Team ini secara umum dapat terdiri dari personil-personil sebagai berikut.

1. Manajer Analis Sistem

2. Ketua Analis Sistem

3. Analis Sistem Senior

4. Analis Sitem

5. Analis Sitem Junior

6. Programer Aplikasi Senior

7. Programer Aplikasi

8. Programer Aplikasi Junior 


\section{ANALISIS SISTEM YANG SEDANG BERJALAN \\ 3.1 Permasalahan yang Timbul}

Dalam proses penggunaan aplikasi sisfo akademik di unipdu jombang masih belum sesuai dengan nilai ukur dari analisis PIECES, terkendala kurang akuratnya hasil keluaran yang dibutuhkan, kurang fleksibelnya aplikasi sisfo akademik terhadap user, dan kendala pada jaringan komputer yang berada pada gedung fakultas lain. User yang belum menguasai karakteristik sistem akan menjadikan pekerjaan lebih lambat. Software aplikasi masih ada yang belum sesuai dengan kurikulum pada beberapa jurusan, belum ada pengembangnya sehingga beban masalah semakin bertambah.

\subsection{Identifikasi Penyebab Masalah}

Beberapa masalah pokok tersebut diatas dapat timbul karena beberapa faktor. antara lain :

a. Penyebab masalah pada pengembangan sistem aplikasi sisfo akademik yang belum baik.

b. Penyebab masalah pada rancang bangun sistem perangkat keras yang buruk

c. User yang minat belajar mengembangkan kemampuan bekerja menggunakan aplikasi sisfo kampus kurang optimal

d. Belum terbentuk nya devisi khusus untuk menangani pengembangan teknologi sistem informasi akademik di Unipdu Jombang

\subsection{Identifikasi Titik Keputusan}

Perlu adanya devisi khusus untuk menangani sistem informasi akademik di unipdu jombang yang sebetulnya telah membuat sistem akademik di unipdu ini menjadi lebih baik dari tahun-tahun sebelumnya. Sehingga jika ada user yang menggunakan sisfo akademik mengalami kesulitan bisa langsung menghubungi devisi tersebut agar segala permasalahan cepat diatasi. Devisi pengembangan sistem ini terdiri dari :

1. Kepala pengembangan sistem dan organisasinya yang akan membawahi beberapa staf ahli lainya. Dan yang bertanggung jawab pada pimpinan lainya serta koordinasi dengan pihak-pihak terkait.

2. Staf Developer bidang programer yang mampu mendesain dan memperbaiki program aplikasi sisfo akademik sesuai dengan kebutuhan user.

3. Staf administrator bidang database yang mampu merancang integritas data dalam database sisfo kampus.

4. Staf administrator sistem bidang hardware yang mampu mendisain kebutuhan perangkat keras sesuai dengan karakteristik sistem yang diterapkan.

\section{PENGEMBANGAN SISTEM YANG DIUSULKAN}

Sistem informasi Akademik akan semakin dirasakan manfaatnya apabila selalu dikembangkan sesuai dengan kebutuhan serta pelatihan bagi para user. Untuk mencapai tujuan yang diinginkan tentu yang paling utama adalah membentuk divisi khusus yang disebut devisi pengembangan sistem agar semua permasalah yang dihadapi mampu ditampung dan ditangani oleh devisi pengembangan yang telah ada.

User atau pengguna aplikasi sisfo akademik ini adalah yang bertanggung jawab disetiap fakultas merupakan Kepala Tata Usaha kemudian Kepala Jurusan, dalam mengoperasikan aplikasi ini, para user bisa memberikan masukan atau meminta kepada devisi pengembangan sistem tentunya dengan prosedur administratif untuk mengembangkan program yang dirasa masih ada kelemahan ataupun kekurangan dalam memproses data akademik sesuai dengan ketentuan kurikulum fakultas yang berlaku.

Dokumen yang telah diusulkan oleh user akan menjadi landasan dasar dalam menganalisis pengembangan sistem. Ini merupakan langkah audit sistem, agar sistem bisa berkembang dengan terorganisir secara keseluruhan. 
Dalam hal ini yang paling berpengaruh terhadap sistem informasi akademik adalah tampilan antarmuka aplikasi harus mudah digunakan, mudah dimengerti dan sesuai dengan kebutuhan data yang akan dimasukkan. Selanjutnya kebutuhan database yang juga harus bisa dikembangkan mengikuti kebutuhan input data agar data bisa terekam, tersimpan dengan baik.

Dalam pengembangan sistem yang dibutuhkan di unipdu tidak memerlukan struktur organisasi yang besar. Hanya beberapa bagian yang sangat dibutuhkan yaitu dipartement pengembangan sistem yang dikepalai oleh manajernya sendiri. Dan departemen pengolah data disini bisa dikepalai oleh kepala biro akademik agar lebih menguasai data yang diolah di unipdu jombang.dengan demikian fungsi dari masing masing bagian adalah sebagai berikut :

a. Manajer sistem informasi mempunyai tugas melakukan perencanaan sistem berdasarkan kebutuhan dan kebijakan universitas

b. Departemen pengembangan sistem mempunyai tugas untuk mengembangkan sistem sesuai rencana yang telah dibuat oleh manajer atau perencanaan sistem

c. Departemen pengolahan data mempunyai tugas untuk mengoperasikan sistem yang telah dikembangkan oleh departemen pengembangan sistem

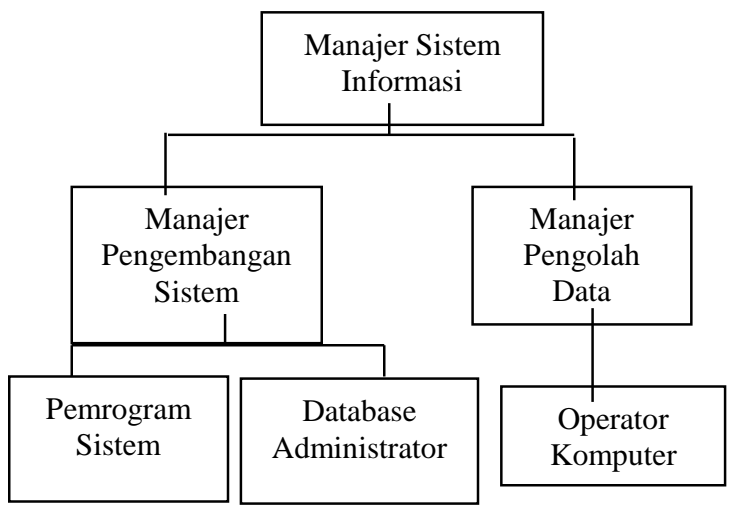

Gambar 2. struktur organisasi yang diusulkan

\section{Rancangan Kendali}

Suatu sistem merupakan subyek dari missmanagement, kesalahan-kesalahan, kecurangan dan penyelewengan umum lainnya. Untuk mencegah, maka harus diterapkan pengendalian dalam bentuk informasi tersebut. Pengendalian dapat dikategorikan ke dalam pengendalian secara umum dan pengendalian aplikasi.

1. Perlengkapan keamanan melindungi perlengkapan komputer, program, komunikasi, dan data dari akses yang tidak sah, modifikasi atau penghancuran.

2. Pengembangan dan perolehan program dilaksanakan sesuai dengan otorisasi khusus dan umum dari pihak manajemen.

3. Modifikasi program dilaksanakan dengan otorisasi dan persetujuan dari pihak manajemen.

4. Pemrosesan transaksi, file laporan dan catatan komputer lainnya telah akurat dan lengkap.

5. Data sumber yang tidak akurat atau yang tidak memiliki otorisasi yang tepat diidentifikasi dan ditangani sesuai dengan kebijakan manajerial yang telah ditetapkan.

6. File data komputer telah akurat, lengkap dan dijaga kerahasiaannya.

\section{Tujuan 1}

\section{Keamanan secara keseluruhan}




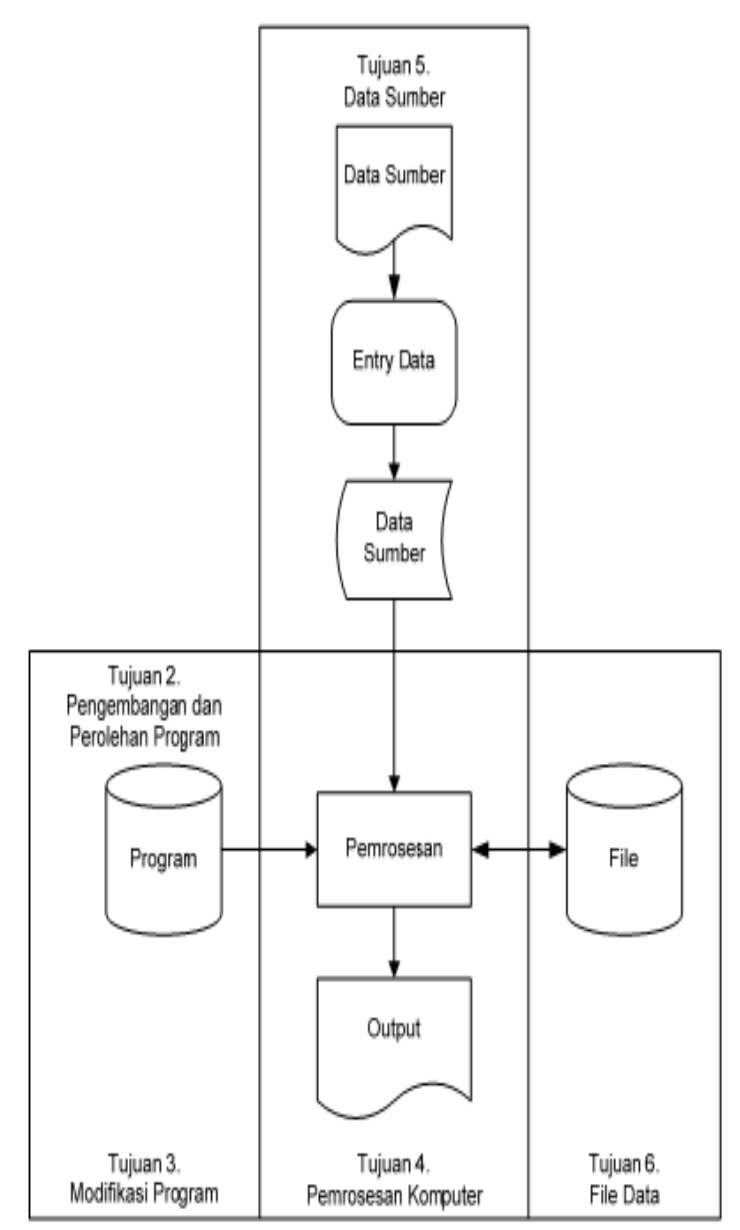

Gambar 3. Komponen Sistem Informasi dan tujuan pengembangannya

\section{Tahap Implementasi}

Pada tahap implementasi ini akan diterapkan sistem yang telah dirancang untuk dapat dioperasikan pada keadaan yang sebenarnya. Sehingga pada langkah ini dipastikan apakah sistem yang diajukan benarbenar dapat menghasilkan tujuan yang diinginkan dengan lebih efektif dan efisien, selanjutnya apakah sistem tersebut masih dapat diperbaiki lagi atau tidak.

\section{Kegiatan Implementasi}

Dalam kegiatan implementasi dilakukan dengan enam tahap yaitu:

1. Pemilihan dan pelatihan personil.

2. Instalasi perangkat keras dan perangkat lunak.

3. Pemrograman dan pengetesan program.

4. Uji coba sistem.

5. Konversi sistem.

6. Evaluasi

Merencanakan implementasi

Tahap ini bertujuan menyiapkan segala kebutuhan yang diperlukan untuk implementasi, sepeti kebutuhan biaya dan waktu implementasi.

\section{Melakukan kegiatan implementasi}




\section{Kegiatan yang dilakukan berupa:}

a. Mendapatkan atau memilih sumber daya hardware, dan software. Hardware yang dipilih disesuaikan dengan konfigurasi, begitu pula dengan software.

b. Menyiapkan database secara tepat disesuaikan dengan software aplikasi/program yang digunakan.

c. Melakukan pengujian atau pengetesan awal sistem untuk mengetahui apakah sistem sudah berjalan atau beroperasi dengan baik. Jika ternyata belum, maka harus dilakukan perbaikan ulang.

\section{Menyiapkan personil}

Personol disiapkan dengan terlebih dahulu memberikan pelatihan dalam bentuk ceramah/seminar, pelatihan secara prosedural maupun tutorial mengenai sistem informasi sesuai fungsi tugasnya. Tujuannya adalah agar para personil mengerti dan menguasai operasi sistem dan cara kerja sistem serta apa saja yang diperoleh dari sistem. Pemilihan personil dilakukan melalui 2 sumber, yaitu: dari personil yang telah ada dalam organisasi atau personil baru yang berasal dari luar organisasi.

\section{Menyiapkan fasilitas fisik}

Fasilitas-fasilitas fisik yang disiapkan antara lain: lokasi atau ruangan untuk server dan client, tempat untuk komputer dan periferalnya termasuk keamanan fisik untuk menjaga berlangsungnya peralatan dalam jangka waktu yang lama seperti:

pemasangan AC agar udara ruangan tetap sejuk, penerangan yang cukup dan power supply cadangan/UPS.

\section{Melakukan simulasi}

Kegiatan simulasi berupa pengetesan sistem secara nyata yang melibatkan personil yang sesungguhnya. Langkah ini dapat disebut sebagai langkah pengetesan awal.

\section{Konversi sistem (beralih ke sistem yang baru)}

Konversi sistem merupakan tahapan yang digunakan untuk mengoperasikan sistem baru dalam rangka menggantikan sistem yang lama. Proses konversi sistem yang dilakukan menggunakan pendekatan konversi percontohan (pilot approach) dengan menerapkan sistem yang diusulkan pada bagian kepegawaian terlebih dahulu sambil dinilai operasinya dalam bagian tersebut. Apabila sistem yang baru dianggap telah dapat beroperasi dengan baik, maka penerapan sistem akan dilanjutkan pada bagian yang lain. Hal ini dilakukan dengan tujuan untuk:

1. Menghindari resiko kegagalan hanya pada bagian tertentu;

2. Memperbaiki kesalahan yang terjadi dengan segera bila ditemukan kesalahan, untuk menghindari kesalahan terjadi di bagian yang lain;

3. Melatih personil di bagian lain pada bagian percontohan dalam situasi nyata sebelum sistem diterapkan pada situasi kerjanya.

Adapun tahap-tahap konversi yang akan dilakukan antara lain:

a. Konversi dokumen dasar, dengan mengganti dokumen dasar lama yang tidak sesuai lagi dengan input sistem informasi dengan dokumen dasar yang baru untuk sistem baru.

b. Konversi file, dilakukan secara manual dengan cara mencetak isi file lama ke media kertas terlebih dahulu dan dimasukkan ulang ke file baru lewat media input, yaitu keyboard.

c. Pengoperasian sistem yang baru dilakukan setelah 2 konversi di atas selesai dilakukan.

\section{Evaluasi sistem}

Evaluasi sistem dilakukan setelah sistem yang baru diimplementasikan. Kegiatan ini dilakukan dengan mengadakan pengetesan penerimaan sistem (systems acceptance test), menggunakan data-data yang sesungguhnya untuk jangka waktu tertentu. Pengetesan dilakukan oleh analis sistem bersama user. Jika hasil dari pengetesan sistem ini dapat diterima atau disetujui, maka sistem dapat diserahkan kepada user. Namun jika sistem masih perlu diperbaiki kembali, maka sistem diperbaiki terlebih dahulu sebelum akhirnya diserahkan. Tugas analis sistem dapat dikatakan selesai bila penyerahan sistem terjadi.

\subsection{Penggunaan sistem}


Yaitu menggunakan sistem sesuai dengan fungsi tugasnya masing-masing untuk operasi rutin atau sehari-hari.

\subsection{Audit sistem}

Yaitu melakukan penggunaan dan penelitian formal untuk menentukan seberapa baik sistem baru dapat memenuhi kriteria kinerja. Hal semacam ini disebut penelaahan setelah penerapan dan dapat dilakukan oleh seorang auditor internal.

\subsection{Penjagaan sistem}

Yaitu melakukan pemantauan untuk pemeriksaan rutin sehingga sistem tetap beroperasi dengan baik. Selain itu juga

untuk menjaga kemutakhiran sistem jika sewaktu-waktu terjadi perubahan lingkungan sistem atau modifikasi rancangan software.

\subsection{Perbaikan sistem}

Yaitu melakukan perbaikan jika dalam operasi terjadi kesalahan (bugs) dalam program atau kelemahan rancangan yang tidak terdeteksi saat tahap pengujian sistem.

\subsection{Peningkatan sistem}

Yaitu melakukan modifikasi terhadap sistem ketika terdapat potensi peningkatan sistem setelah sistem berjalan.

\section{KESIMPULAN}

Dalam perencanaan dan mendesain sistem informasi tentunya tidak bisa hanya dikira-kira untuk mencapai sebuah tujuan. Tetapi harus mengerti tentang prosedur dalam pembuatan sistem hingga mendapatkan tujuan yang diinginkan. Sistem informasi akademik unipdu jombang yang telah di implementasikan adalah hasil perencanaan yang implementasinya masih mengalami banyak kendala dikarenakan tahap-tahap implementasi belum sesuai dengan prosedur teknik pengembangan sistem.

Untuk mendapatkan tujuan yang seharusnya dibutuhkan pengetahuan yang cukup agar tidak terjadi permasalahan disaat implementasi sistem. Analisis sistem selalu dibutuhkan dalam merencanakan kebutuhan sistem yang akan diadakan guna mendapatkan sumberdaya dan komponen-komponen sistem yang tepat.

Pengembangan sistem adalah sesuatu yang selalu ada pada setiap sistem informasi, agar sistem selalu mampu dioperasikan sesuai dengan kebutuhan disaat ini maupun kebutuhan yang akan datang.

Maka tidak akan mungkin jika ada sistem yang tidak perlu dikembangkan. Oleh karena itu perlu adanya organisasi yang baik guna menangani sistem yang menjadi fasilitas penting disetiap lembaga khususnya sistem informasi akademik di unipdu jombang.

Kualitas Informasi

1. Akurat (bebas dari kesalahan)

2. Tepat pada waktunya

3. Relevan (bermanfaat)

Nilai Informasi ditentukan oleh :

1. Manfaat.

2. Biaya mendapatkannya. 


\section{DAFTAR PUSTAKA}

HM, Jogiyanto. 1990. Analisis \& Disain Sistem Informasi: Pendekatan Terstruktur Teori dan Praktek Aplikasi Bisnis. Yogyakarta: Penerbit ANDI OFFSET.

Jeffrey L.Whitten, Lonnie D.Bentley, Kevin C.Dittman, System Analysis and Design Methods 5th Edition,Mc Graw-Hil. 